\title{
Wordsworth As A Humanitarian
}

\author{
Faria Saeed Khan \\ Department of English University of Balochistan, Quetta, Pakistan
}

\begin{abstract}
The sufferings and the oppression of the French people caused sorrow and concern in the heart of every sensitive soul in Europe. Wordsworth was one of the staunch supporters of the French Revolution. He had a close experience with the Revolution. But the tragic aftermath of the Reign of Terror and Napoleonic wars cooled his revolutionary zeal. Even though he never accepted political or social oppression, in the eyes of the radicals he became known as a traitor and an escapist.

Wordsworth was not a traitor or an escapist. He was a humanitarian who throughout his life struggled for human welfare. This research article will study Wordsworth as a humanitarian.
\end{abstract}

\section{Introduction}

The Romantic period in English literature coincides with the French Revolution. The Romanticists were influenced by the ideals of the Revolution. According to Day:...humanitarian sympathy was part of the ground-swell of radical political feeling in the last quarter of the eighteenth century, the period which saw first the American War of Independence and then the French Revolution.' (Day:1996,12)1

The romanticists believed in equality and freedom of mankind. They were liberals, conservatives, rationalists, idealists, Catholics, atheists, revolutionaries and reactionaries. Shelley believed that man must be liberated from all kinds of oppression. He thrived with a craving to unshackle mankind from the clutches of morbidity and lack of liberty. This lent to his poetry an elemental force, a vehemence as vigorous as that of the Wild West Wind. The poem puts across Shelley's spirit of liberty which is tempestuous and prevailing as the West Wind itself. The poet addresses the west wind and beckons his spirit to descend upon him and act through $\backslash$ his lips as the trumpet of a prophecy to the indifferent world. Shelley depicts the impact of the West wind on the dead leaves of autumn. They are driven by the west wind as ghosts fleeing from an enchanter. The wind forces them to their wintry bed where they will stay buried like a corpse till the clarion call of spring shall arouse them to a new life. It destroys the old decaying leaves. It scatters the seeds and thus preserves life. Likewise, the poet looks forward that the stagnant conventions die and make way for regeneration.

The theme of the West Wind is sustained in Shelley's poem Queen Mab also. The poem illustrates Shelley's wrath at economic injustice in the world. He thought that ' there is no real wealth but the labour of man. Were the mountains of gold and the valleys of silver, the world would not be one grain of corn the richer; no one comfort would be added to the human race. One man is enabled to heap to himself luxuries at the expense of the necessaries of his neighbour; a system admirably fitted to produce all the varieties of disease and crime. A speculator takes pride to himself as the promoter of his country's prosperity, who employs a number of hands in the manufacture of articles subservient to the cravings of luxury and ostentation. The poor are set to labour, not the food for which they famish: not the blankets for want of which their babes are frozen by the cold of their miserable hovels: not those comforts of civilization without which civilized man is far more miserable than the meanest savage;....'( http://www.humanism-cotland.org.uk/what-is-humanism/essay-onhumanism-5.html) 2

Byron was also a rebel poet . His Byronic hero is his mouth piece with regard to his intellectual capacity, self-respect, and hypersensitivity. He is "larger than life." and is usually isolated from society in exile of some kind. Byron's characters wander desolate mountaintops, and are physically isolated from society. 'Childe Harold chose to "exile" himself and wander throughout Europe. Although Harold remained physically present in society and among people, he was not by any means "social." Often the Byronic hero is moody by nature or passionate about a particular issue. He also has emotional and intellectual capacities, which are superior to the average man. These heightened abilities force the Byronic hero to be arrogant, confident, abnormally sensitive, and extremely conscious of himself. In one form or another, he rejects the values and moral codes of society and because of this he is often unrepentant by society's standards. Often the Byronic hero is characterized by a guilty memory of some unnamed sexual crime. Due to these characteristics, the Byronic hero is often a figure of repulsion, as well as fascination.'

http://www.umd.umich.edu/casl/hum/eng/classes/434/charweb/CHARACTE.htm 3

Don Juan also offers commentary on war, religion, restraints on personal liberty and freedom of speech, and injustices rendered upon society's weakest inhabitants. A passive character, Byron's Juan reacts to the world around him. Brave, resourceful, but without motivation or direction, he is a victim of a harsh, hypocritical 
world. By casting outside forces as corrupting influences on a character traditionally depicted as extravagant and callous, Byron reversed popular legend to suggest that society, not the individual, bears responsibility for evil in the world.

The French Revolution was not just a historical event, it influenced the intellectual, philosophical, and political life in the nineteenth century. Thomas Paine and William Godwin saw it as an act which indicated the return of humanity to the state of perfection from which it had fallen away. But Edmund Burke denounced the Revolution in his Reflections on the Revolution in France. Tom Paine responded and in his book The Rights of Man he writes:

'Every history of the creation, and every traditional account, whether from the or unlettered world, however they may vary in their opinion or belief of certain particulars, all agree in establishing one point, the unity of man; by which I mean, that men are all of one degree, and consequently that all men are born equal, and with equal natural right, in the same manner as if posterity had been continued by creation instead of generation, the latter being only the mode by which the former is carried forward; and consequently, every child born into the world must be considered as deriving its existence from God.The world is as new to him as it was to the first man that existed, and his natural right in it is of the same kind.' ( Paine, cited in Dickinson,1974:183)4

Godwin thought that nothing can hinder man in attaining perfection in life. Godwin's opinions, in Political Justice places human mind on elevation which commands a whole line of moral consequences. Godwin is of the view that 'Democracy is a system of government, according to which every member of society is considered as a man, and nothing more. So far as positive regulation is concerned, if indeed that can, with any propriety, be termed regulation, which is the mere recognition of the simplest of the moral principles, every man is regarded as equal. Talents and wealth, wherever they exist, will not fail to obtain a certain degree of influence, without requiring positive institution to second their operation....Democracy restores to man a consciousness of his value, teaches him, by the removal of authority and oppression, to listen only to the suggestions of reason, gives him confidence to treat all other men with frankness and simplicity, and induce him to regard them no longer, as enemies against him to assist. The citizen of a democratical state, when he looks upon the oppression and injustice that prevail in the countries around him, cannot but entertain an inexpressible esteem for the advantages he enjoy, and the most unalterable determination to preserve them....'(Godwin, Cited in;Dickinson,1974:204-205)5 Godwin absolves man from the gross and narrow ties of sense and customs. Andrew Sanders in his book The Short History Oxford History of English Literature writes that Godwin views human happiness and social well being as the sole purpose of existence, but unlike Rousseau he looks forward to a gradual melting away of all government to be replaced by a new system of radical anarchy. A rigid adherence to the leading principle of reason is substituted for Rousseau's cult sensibility and his innate religiosity. Law government, property, inequality and marriage would be abolished as part of a gradual process by which human perfectibility, conditioned by human reason, would transcend existing limitations and impediments to fulfilled happiness.' ( Sanders,1994:342)6

Godwin's hatred for all forms of injustice is reflected in his novels such as Adventures Of Caleb Williams.The novel depicts the problems of class distinction and the nature of oppression. Godwin is less concerned with the authority of the state and more with the exercise of power by a privileged class. Caleb Williams, hero of the novel, imprisoned by one of the persecutor exclaims 'Is that a country of liberty where thousands languish in dungeons and fetters? Go, go ignorant fool ! and visit the scenes of our prisons! Witness their unwholesome, their filth, the tyranny of their governors, the misery of their inmates!' (Cited in Sanders, 1994:342) 7 Caleb's character plays the role of a critic and points out the ills of English society adding to it a penetrating radical colour.

For Burke the French Revolution was the most astonishing event that happened in the world. During the American Revolution he was leader of the liberals and believed that the revolution of 1688 is :most wise, sober, and considerate declaration, 'drawn up by great Lawyers and great statesmen, and not by warm and inexperienced enthusiasts....to choose our own governor; to cashier them for misconduct ; and to form a government for ourselves... The revolution was made to preserve our ancient constitution of government which is our only security for law and liberty' ( Burke,Cited in Dickinson,1974:177) 8 Burke took French Revolution as his worst enemy and in the course of this campaign he made a major contribution to political philosophy. $\mathrm{He}$ declared that the doctrines of the French Revolution would spread beyond the frontiers of France and subvert the foundations of existing political institutions and social order. He pointed out the danger of all attempts to alter suddenly the institutions of nation. He thought that the French had proved themselves a great destructive force; they had destroyed their government and their church, and stuck a dangerous blow at the rights of property. Burke was revolted by the triumph of mob over a most lawful and mild king, treating him with more fury and insult than ever raised against any unlawful monarch. Burke says that 'Our political system is placed in a just correspondence and symmetry with the order of the world, and which the mode of existence decreed to a permanent body composed of transitory parts; wherein, by the disposition of a stupendous wisdom ,moulding together the great mysterious incorporation of the human race, the whole, at one time, is never old, or middle 
aged, or young, but, in a condition of unchangeable constancy, moves on through the varied tenor of perpetual decay,fall,renovation, and progression. Thus, by preserving the method of nature in the conduct of the state, in what we improve, we are never wholly new; in what we retain, we are never wholly new; in what we retain, we are never wholly obsolete. By adhering in this manner not by the superstition of antiquarians, but by the spirit of philosophic analogy..... ( Burke cited in Dickinson:1974:178)9

\section{In Reflections on the Revolution in France he writes:}

'I flatter myself that I love a manly, moral, regulated liberty as well as any gentleman...But I cannot stand forward, and give praise or blame to anything which relates to human actions, and human concerns, on a simple view of the objects, as it stands stripped of every relation, in all the nakedness and solitude of metaphysical abstractions. Circumstances (which with some gentlemen pass for nothing) give in reality to every political principle its distinguishing colour and discriminating effects. The circumstances are what render every civil and political scheme beneficial or noxious to mankind....Is it because liberty in the abstract may be classed amongst the blessings of mankind, that I am seriously to felicitate a mad man, who has escaped from the protecting restraint and wholesome darkness of his cell, on his restoration to the enjoyment of light and liberty. Am I to congratulate a highwayman and murderer, who broke prison, upon the recovery of his natural rights? A spirit of innovation is generally the result of a selfish temper, and confined views, People will not look forward to posterity, who never look backward to their ancestors ( Burke Cited in ,Dickinson:1974,177-178)10

The French Revolution was a potent force which deeply influenced many English poets, writers and thinkers and Wordsworth was one of them. Frye in his book Fearful Symmetry. A Study of William Blake, says '[Wordsworth's poetry] partakes of, and is carried along with, the revolutionary movement of our age: the political changes of the day were the model on which he formed and conducted his political experiment. His muse is a leveling one. It proceeds on a principle of equality, and strives to reduce all things to the same standard .....The distinction of rank, birth, wealth, power... are not to be found there..' (Cited in Day,1996:127) 11

Earnest De Selin, believes that in 1791-1792 Wordsworth's love from nature shifted to love for man and this coincides with his plunge into humanitarian politics in France. In France he witnessed a diseased social order that gave way to utter debasement of humanity. He witnessed social privileges of aristocracy, the class oppression, legal disabilities, economic shortages, high price and military threats, all resulting from the corruption in the established social order. Wordsworth was brought up in a rustic society where equality was accepted as a matter of course and people lived on the terms of equality. Wordsworth's temper was essentially democratic. He was touched by the miseries of oppressed people in France. He developed hatred for the ruling classes. He thought that the monarchy is bringing about its own destruction. He perceived the deficiencies of the old government and its absolute indifference to the plight of its citizens. He saw the miseries of common people and the luxuries of the monarchy. Closely related to monarchial government was the aristocratic status quo. They had absolute control of the wealth and privileges

Wordsworth visited France in 1790. At that time Paris was celebrating the first anniversary of the fall of Bastille. Wordsworth was affected by the enthusiasm and joy of the French people. He saw with amazement the revolution sweeping away the old regime. He went to France for the second time in 1791 and stayed there for a longer period of time. This is the year when Wordsworth stepped into the first phase of his political development.

The French Revolution began as an upheaval against monarchial abuse of power that was eradicating liberty among the lower middle classes in France. The corruptions of the upper class, in France, pointed to the corruptions of establishment in England. Wordsworth supported the French Revolution because he desired social change for the betterment of humanity. According to Walsh 'Wordsworth's radicalism was an attitude of mind... by variety of circumstances- by an aversion to the aristocracy by the independent character of the small landholders amongst whom he had passed his early years; by his experiences in France and his tutelage at the hands of the soldier Beaupuy...'( Walsh,H.J,1963:10) 12 Wordsworth viewed the outbreak of the French Revolution as a momentous event. It was a moment of great rejoicing for him. Wordsworth's revolutionary zeal was infused with his spirit of love for humanity. For him, it was a blessing to be alive on that occasion. Wordsworth, expressing his joy over the change and says, 'Oh! Pleasant exercise of hope and joy!' Pinion was of the view that: Wordsworth's poems communicate some of the romantic intoxication he experienced thirteen years earlier in France. Its tragic sequence of events is movingly and more effectively narrated than some critics allow.' (Pinion,1984:34) 13

Wordsworth attacked the hypocrisies and cruelties of the ruling classes. He was in France during 1791-92. Captain Beaupuy became one of his closest friends in France.. According to Johnston 'Beaupuy was happy to meet an Englishman in Blois, especially one so ripe for the final states of conversion to the good cause...... Wordsworth was of roughly the same class and educational background made him all the more attractive to the busy young captain.(Johnston,1998:302) 14 
Wordsworth idealized Beaupy. In his company Wordsworth became an ardent republican. He says that his 'heart was all given to people and his love was theirs.' The two friends walked along the forest tracks. Beaupuy's stories of the past wrongs of the rulers grieved the poet. Many sights of human sufferings in France due to poverty and political oppression made Wordsworth believe that the spirit of revolution was unconquerable. Wordsworth says: Meantime, day by day, the roads/ Were crowded with the bravest Youth of France,/ And all the promptest of her Spirits, link'd /In gallant Soldiership, and posting on/ To meet the War upon her Frontier Bounds. /Yet at this very moment do tears start Into mine eyes; ....(263-270)

Beaupuy discussed with Wordsworth all the important issues of the time. Pinion says 'His influence on Wordsworth never faded; he strengthened the poets belief in common man, 'Man he loved as man,' however mean and obscure; he believed in the nobility of his nature, a given gift which made him capable of seeingclear truth and of building liberty.' (Pinion,1984:35)15 When Britain declared war on the Republic. Wordsworth felt disgusted. He hated the king's regent and ministry for attacking the newly formed Republic. He was an ardent republican and in his sonnet Dedicated To Liberty And Order Wordsworth writes:

People your chain are serving link by link

Soon shall the rich be leveled down the poor

Let us break forth in tempest now or never!

In his poems he depicted gruesome war scenes. In The Female Vagrant, the vagrant woman narrates her tragic story and says:

All perished -all, in one remorseless year

Husband and children! one by one, by sword

And ravenous plague, all perished.

When the French Revolution passed into the Reign of Terror power went into the hands of mob. The king was condemned to death and guillotined. First the Royalist were beheaded then the moderate Girondins. More than thousand individuals were guillotined in forty- seven days. According to the London Times

'In different prisons, churches, and convents, the mob amused themselves with their victims, and formed a mock Tribunal. Some idea of these infamous proceedings may be collected from the following barbarities exercised on the old Cardinal DE LA ROCHEFAUCAULD. His hands and feet were tied together; and the mob ordered him to acknowledge that during his whole life he had never believed in God, but had been a hypocrite. He made no answer. The mob then said, if you believe in God, we give him, the Virgin Mary or her bastard John, five minutes to release you; and so saying they cut him to pieces.

Other prisoners were asked what they did when they were last with their wives, mistresses, and such other indecent, vaunting expressions. Others again were asked what they thought their parents at Coblentz would say on hearing of their death, \&c. Questions of this nature were particularly put to the women.

The mob ordered one of the Swiss solders to dress the hair of a young Swiss officer, a very handsome young man; and when it was done, they ordered him with a hand-saw to take off his head, and to be cautious not to spoil his headdress, saying it was too fine a head to put upon a pike, but to the best advantage. The soldier refused to obey, and was immediately cut to pieces; and two women sawed the officer's head from his body. He was not heard to make the least complaint, and it was near an hour before the head was quite off At the Place Dauphin, the mob had made a fire, and before it several men, women, and children were roasted alive. The countess PERIGNAN with her two daughters, the daughters first, and the mother after, were stripped of their cloaths, washed with oil, and roasted alive, while the mob were singing and dancing round the fire, and amusing themselves with their cries and sufferings. After the repeated prayers of the eldest girl, not more than 15 years old, that some one would with a sword or a pistol put an end to her horrid existence, a young man shot her through the heart, which so irritated the mob, that they immediately threw him into the fire, saying, he should suffer in her place. When the mother was roasted, the mob brought six priests to the same fire and then cutting some flesh from the body, ordered the Priests to eat it. They all of them approached the horrid scene with their eyes shut, and did not speak a word in answer. The mob directly undressed the eldest of them, a man about 60, and roasted him; saying, they perhaps might like the flesh of their friends better than that of the Countess. The other five instantly threw themselves into the fire, and were burnt to death, embracing each other; and though the mob did every thing they could to get them out of the fire, in order a little to prolong their sufferings, they could not effect it, as the fire was extremely fierce. This happened about ten o'clock on Monday night.' (http://www.english.ucsb.edu/faculty/ayliu/research/around-1800/FR/times-9-12-1792.html) 16

Wordsworth was extremely disappointed and scared. Expressing his fears in The Prelude,he says:

But that night I felt most deeply in what world I was,

What ground I trod on, and what air I breathed.

High was my room and lonely, near the roof

Of a large mansion or hotel, a lodge

That would have pleased me in more quiet times;

Nor was it wholly without pleasure then. 
With unextinguished taper I kept watch,

Reading at intervals; the fear gone by

Pressed on me almost like a fear to come.

I thought of those September massacres,

Divided from me by one little month,

Saw them and touched: the rest was conjured up

From tragic fictions or true history,

Remembrances and dim admonishments.

The horse is taught his manage, and no star

Of wildest course but treads back his own steps;

For the spent hurricane the air provides

As fierce a successor; the tide retreats

But to return out of its hiding-place

In the great deep; all things have second birth;

The earthquake is not satisfied at once;

And in this way I wrought upon myself,

Until I seemed to hear a voice that cried,

To the whole city, "Sleep no more."

Wordsworth felt that the ideals of the revolution had been betrayed so he ceased to support the Revolution.

In A Letter To The Bishop Of Llandaff, Wordsworth states, You say 'I fly with terror and abhorrence even from the altar of liberty when I see it stained with the blood of the aged, of the innocent, of the defenceless sex; of the ministers of religion, and of the faithful adherents of the fallen monarch..... What! Have you so little knowledge of the nature of man as to be ignorant, that at a time of revolution is not the season of true Liberty. Alas! The obstinacy \& perversion of men is such that she is too often obliged to borrow the very arms of despotism to overthrow him, and in order to reign in peace must establish herself by violence. . . Political virtues are developed at the expense of moral ones; ... It is the province of education to rectify the erroneous notions which a habit of oppression ... may have created ... ; it belongs to her to create a race of men who, truly free, will look upon their fathers as only enfranchised.' (http://www.arts.ualberta.ca/ dmiall/TinternRev/Ames_3.htm) 17

In 1794, under the leadership of Nepoleon Bonaparte France began to take away the liberty of other countries. In one of his sonnets Napoleon As Fallen Angel he writes

LOOK now on that Adventurer who hath paid

His vows to fortune; who, in cruel slight

Of virtuous hope, of liberty, and right,

Hath followed wheresoe'er a way was made

By the blind Goddess ; - ruthless, undismayed;

And so hath gained at length a prosperous Height,

Round which the Elements of worldly might

Beneath his haughty feet, like clouds, are laid.

$\mathrm{O}$ joyless power that stands by lawless force!

Curses are his dire portion, scorn, and hate

Internal darkness and unquiet breath;

And, if old judgments keep their sacred course,

Him from that Height shall Heaven precipitate

By violent and ignominious death.

After the failure of the French revolution, Wordsworth became mentally disturbed because he realized that his belief in the Golden Age was ending in horror and atrocities in . He blamed the French people for Napoleon's rise to power in Calais, August, 1802, he says:

Ye men of prostrate mind,

A seemly reverence may be paid to power;

But that's a loyal virtue, never sown

In haste, nor springing with a transient shower:

When truth, when sense, when liberty were flown,

What hardship had it been to wait an hour....Slavery prone!

Wordsworth was disillusioned, and disappointed. In The Prelude he writes:

Domestic carnage now filled all the year

With Feast-Days; the old Man from the chimney- nook,

The Maiden from the bosom of her Love 
The Mother from the cradle of her babe,

The Warrior from the Field, all perish'd, all,

Friends, enemies, of all parties, ages ranks,

Head after head, and never heads enough

For those that bade them fall: ..(BK X, 336-342)

Lamenting the time in The Prelude and writes:

It was a lamentable time for man

Whether a hope had e'er been his or not,

A woeful time for them whose hopes did still

Out last the shock; most woeful for those few,

They had the deepest feeling of the grief,

Who still were flattered, and had trust in man. (BK X,387-392)

Purkis is of the view that 'Wordsworth was intensely politically conscious all his life; he may have changed sides, but he never lost interest in the battle. He is indeed the most political of all our poets and this is hardly surprising when we remember that he grew up in an age of Revolutions.'(Purkis,2003:20)17 Wordsworth had witnessed enough of bloodshed and horror in France. He accepts conservatism and follows the principles advocated by Edmund Burke. He realized that like an oak Burke's constitution was organic, time honored, slow to change and grow, protective of the subjects who sheltered beneath it. He compares Burke to an oak tree, acknowledging the power of his symbol as an anti- revolutionary- a conservative. In The Prelude he says:

I see him,- old but vigorous in age,

Stand like an oak whose stag-horn branches start

Out of its leafy crown, the more to awe

The younger brothern of the groove.

While he forewarns, denounces, launches forth,

Against all systems built on abstract rights,

Keen ridicule; the majesty proclaims

Of institutes and laws, hallowed by time;

Declares the vital powers of social ties

Endeared by custom; and with high disdain,

Exploding upstart

As a conservative Wordsworth preaches that there must be respect for institutions, tradition, religion and judgment of community because it is formed after thousands of experiments in the great laboratory of time. Change, for Wordsworth includes no risk of a chaotic social order, but instead entails gradual orderly progress towards a better society. Go slow he warns the advocates of change. Wordsworth does not like volcanic burst and of violent upheaval. He advises the people of England in the following words:

Long favored England!

Be not thou misled

By monstrous theories of alien growth

Lest alien frenzy seize thee.

\section{Conclusion}

For Wordsworth Ideals of freedom remained unattained. Thousands of lives sacrificed in the name of liberty and equality appeared futile as the revolution was followed by the violence of the Reign of Terror and imperialism of Napoleon. He was no more an impatient republican. He believed that a gradual progress bring peace and prosperity in life and violent changes cause disturbance and destruction of humanity. Wordsworth returned to the Lake District. In his sonnet Composed in the Valley near Dover, on the Day of Landing, Wordsworth contrasts the enslavement of Europe with the political freedom still prevailing in his own country. The sonnet speaks of the relief with which he again sets foot on English soil. He expresses his satisfaction in the following lines:

All, all are English.

Oft have I looked round

With joy in Kent's green vales; but never found

Myself so satisfied in heart before.

Europe is yet in bonds;but let that pass,

Thought for another moment.

Thou art free, My Country!

And 'tis joy enough and pride

For one hour's perfect bliss, to tread the grass

Of England once again,... . 


\section{References}

[1] Adian Day: Romanticism,( London: Routledge: 1996)

[2] http://www.humanism-cotland.org.uk/what-is-humanism/essay-on-humanism-5.html

[3] http://www.umd.umich.edu/casl/hum/eng/classes/434/charweb/CHARACTE.htm

[4] Dickinson, ed;Paine, Politics and Literature,(London:J.M.Dent\& Sons Ltd: 1974)183 ibid,204-205

[5] Andrew Sanders, The Short Oxford History of English Literature, (United States:Oxford University Press:2004)342

[6] ibid,342

[7] Dickinson, ed; Burke, Politics and Literature ,(London:J.M.Dent\& Sons Ltd: 1974)177 ibid, 178 ibid,177-178

[8] Adian Day: Romanticism,( London: Routledge: 1996)127 J.H.Walsh,ed; Wordsworth, William Wordsworth: Selection From His Poetry, (London:Chatto And Windus (Educational Ltd:1968)10

[9] F. B Pinion, AWordsworth Champion, (London, The Macmillian Press Ltd:1984)34

[10] Kenneth R.Johnston, The Hidden Wordsworth: Poet.Lover.Rebel.Spy,( New York:W.W.Norton\& Company, Inc:1998)302

[11] F. B Pinion, AWordsworth Champion, (London, The Macmillian Press Ltd:1984)35

[12] http://www.english.ucsb.edu/faculty/ayliu/research/around-1800/FR/times-9-12-1792.html.

[13] http://www.arts.ualberta.ca/ dmiall/TinternRev/Ames_3.htm)

[14] Purkis: Wordsworth, (India:Pearson Education Ltd:2003) 22 